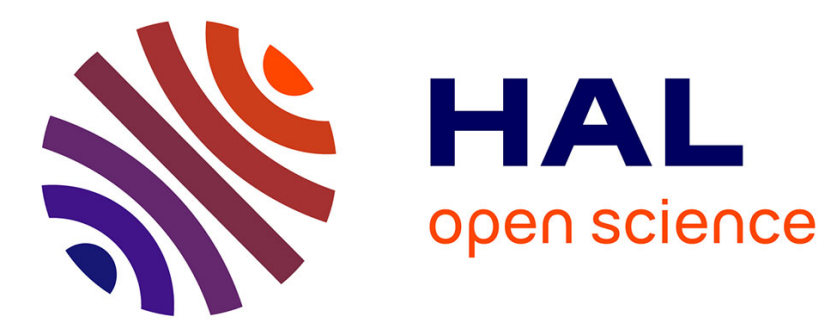

\title{
Tumour targeting of lipid nanocapsules grafted with cRGD peptides.
}

Samuli Hirsjärvi, Camille Belloche, François Hindré, Emmanuel Garcion, Jean-Pierre Benoit

\section{- To cite this version:}

Samuli Hirsjärvi, Camille Belloche, François Hindré, Emmanuel Garcion, Jean-Pierre Benoit. Tumour targeting of lipid nanocapsules grafted with cRGD peptides.. International Journal of Pharmaceutics, 2014, 87 (1), pp.152-9. 10.1016/j.ejpb.2013.12.006 . inserm-00923988

\section{HAL Id: inserm-00923988 https://www.hal.inserm.fr/inserm-00923988}

Submitted on 6 Jan 2014

HAL is a multi-disciplinary open access archive for the deposit and dissemination of scientific research documents, whether they are published or not. The documents may come from teaching and research institutions in France or abroad, or from public or private research centers.
L'archive ouverte pluridisciplinaire HAL, est destinée au dépôt et à la diffusion de documents scientifiques de niveau recherche, publiés ou non, émanant des établissements d'enseignement et de recherche français ou étrangers, des laboratoires publics ou privés. 


\section{Tumour targeting of lipid nanocapsules grafted with cRGD peptides}

Samuli Hirsjärvi ${ }^{\mathrm{a}^{*}}$, Camille Belloche ${ }^{\mathrm{a}}$, François Hindré ${ }^{\mathrm{a}}$, Emmanuel Garcion $^{\mathrm{a} *}{ }^{*}$, Jean-Pierre Benoît $^{\mathrm{a} *}$

a'LUNAM Université, Université d'Angers, INSERM U1066, Angers, France

* Equal contribution

Address: INSERM U1066, IBS-CHU Angers, 4 rue Larrey, 49933 Angers Cedex 9, France

*Corresponding author:

Tel.: +3324468 8545

Fax: +33244688546

E-mail: samuli.hirsjarvi@univ-angers.fr 


\begin{abstract}
Combining targeting to therapy remains a major challenge in cancer treatment. To address this subject, the surface of lipid nanocapsules (LNC) were modified by grafting cRGD peptides, which are known to be recognised by $\alpha_{v} \beta_{3}$ integrins expressed by tumour endothelium and cancer cells. Applicability of this LNC-cRGD in tumour targeting was first assessed in vitro by the use of U87MG glioma cells. Biodistribution and tumour accumulation of radiolabelled LNC-cRGD in vivo were then evaluated in mice bearing the same subcutaneous xenograft. Flow cytometry and confocal microscopy results revealed that the cRGD grafting improved binding and internalization compared to negative control LNCcRAD and blank LNC. The peptide-grafted LNC remained in the blood circulation up to 3 hours with reduced capture by the RES organs. Tumour accumulation of LNC-cRGD with respect to LNC-cRAD was significantly higher at 1-3 hours. These results show that cRGD grafted to LNC has created a promising tumour-targetable nanocarrier that could be used in cancer treatment.
\end{abstract}

Keywords: lipid nanocapsules, cRGD peptide, cellular uptake, targeting, biodistribution. 


\section{Introduction}

Extensive studies on nanoparticles during the last decades have resulted in drug delivery systems that can protect the active substance, improve solubility, and route the drug to specific tissue, cells and other molecular targets in the body [1]. Cancer therapy is one of the areas that benefits considerably from these advances [2]: traditional therapy by systemic administration causes unwanted, non-selective effects of drugs to healthy tissues, and local radiation therapy, if radiotherapy is applied, can provoke inflammation in the nearby tissues and organs. Moreover, cancer cells are able to evolve and, thus, they can develop resistance toward drug molecules [3, 4] or external beam radiation [5]. Thus, combining targeted therapies to chemotherapeutics or internal radiotherapy appears as major challenges to revert resistance of cancer cells.

Most of the drug carrier nanoparticles are composed of polymer or lipid materials [6, 7]. Lipid nanocapsules (LNC) are synthetic particles whose structure can be characterized as a hybrid between polymer nanoparticles and liposomes [8]. LNC are made of less-toxic materials (PEGylated surfactant, lecithin, triglycerides) and their fabrication is based on low-energy organic solvent-free phase inversion process which can be easily scaled up. Their size can be tuned within the range of 20-100 nm [9]. LNC have been used for the delivery of cancer therapeutics [10-13] and other drug molecules [14], macromolecules such as siRNA and DNA [15], and radiotherapeutics [16-18]. In the context of radiotherapy, ${ }^{188} \mathrm{Re}-\mathrm{LNC}$ have been tested for locoregional treatment of glioma in rats by stereotactic administration [18]. A single dose of radiopharmaceutic-loaded LNC injected by convection enhanced delivery provided an efficient treatment in which the radioactive gradient created in the tumour was shown to play the pivotal role. PEG chains on the surface provide stealth properties for LNC [19]. Because 
of their structure which includes a semi-rigid shell, LNC can be further modified by insertion of amphiphilic molecules. This kind of post-insertion allows several benefits like improvement of biodistribution profile [20] or creation of templates for further attachment of active targeting ligands [21, 22].

Targeted drug delivery aims at obtaining a high local concentration of the drug together with a low systemic exposure. In passive targeting, nanoparticles carrying the drug remain long time in the blood circulation due to their unique size and surface properties which also facilitates accumulation in a desired tissue exploiting the tissue specific properties [23]. In active targeting, ligands are attached to the nanoparticle surface. These ligands are recognised by the receptors or other molecular targets expressed either at the cell surface or in the extracellular microenvironment [24]. Local environment of tumour differs from the healthy tissues: it can attract nanocarriers passively and actively. Tumour vasculature is usually leaky which allows the small particles to extravasate, while specific molecules expressed by tumour cells that are not present on normal cells can be used for active targeting. $\alpha_{\mathrm{v}} \beta_{3}$ integrin is overexpressed in both tumour cells and angiogenic endothelial cells, making it a potential target for therapy [25]. Since the discovery that cyclic pentapeptides containing the amino acid sequence ArgGly-Asp (RGD) bind selectively to $\alpha_{v} \beta_{3}$ integrins [26] and they can enhance drug delivery to tumours [27], nanoparticles decorated with RGD-type peptides have been used in drug targeting [28-34]. Glioblastomas are aggressive, highly vascularized brain tumours that display poor patient survival and prognosis with current therapies. These tumours and the associated newly formed vasculature express $\alpha_{\mathrm{v}} \beta_{3}$ integrin [35].

In this study, suitability of LNC as targeting nanocarriers with surface conjugated RGDpeptide was assessed. The peptides tested were cyclic RGD (cRGD) which is known to bind 
to $\alpha_{v} \beta_{3}$ integrin and a negative control cyclic RAD (cRAD) peptide, which does not bind to the receptor. These peptides were grafted on the amphiphilic lipids which were then postinserted into the LNC shell. Performance of these LNC was evaluated in vitro on U87MG glioblastoma cells. In vivo biodistribution was determined in nude mice with subcutaneous U87MG xenograft. The main questions assessed by this study were: could the cRGD peptide be successfully attached on the surface of LNC? Is the ability of this peptide to recognise $\alpha_{v} \beta_{3}$ integrin preserved when combined to LNC (targeting)?

\section{Materials and Methods}

\section{Materials}

Solutol® HS15 (PEG 660 12-hydroxystearate, $M_{\mathrm{W}} \sim 870$ g/mol) (BASF, Ludwigshafen, Germany), Labrafac ${ }^{\mathrm{TM}}$ WL 1349 (caprylic/capric acid triglycerides) (Gattefossé S.A., SaintPriest, France), Lipoid® S75-3 ( $M_{\mathrm{W}} \sim 780$ g/mol) (Lipoid GmbH, Ludwigshafen, Germany), $\mathrm{NaCl}$ (Prolabo VWR International, Fontenay-sous-Bois, France) and deionized MilliQ185 water (Waters, Saint-Quentin-en-Yveline, France) were used in the LNC preparation. 1,1'dioctadecyl-3,3,3',3'-tetramethylindocarbocyanine perchlorate (DiI) was from Invitrogen (Cergy Pontoise, France). cRGD [c(Asp-(d)Phe-Lys( $($-Ata)-Arg-Gly) (acetate)] and cRAD [c(Asp-(d)Phe-Lys( $\left(\right.$-Ata)-Arg-Ala) (acetate)] peptides $\left(M_{\mathrm{W}}\right.$ of both $\left.\sim 600 \mathrm{~g} / \mathrm{mol}\right)$ were from Ansynth Service B.V. (Roosendaal, The Netherlands). 4-(2-hydroxyethyl) piperazine-1ethanesulfonic acid (HEPES), ethylenediaminetetraacetic acid di-sodium ( $\mathrm{Na}_{2}$-EDTA), tris (2carboxyethyl) phosphine hydrochloride (TCEP, 0.5 M), and Sepharose CL4-B were from Sigma-Aldrich (Saint-Quentin-Fallavier, France). 1,2-distearoyl-sn-glycero-3phosphoethanolamine-N-[maleimide (polyethylene glycol)-2 000] (ammonium salt) (DSPE$\mathrm{PEG}_{2000}$-maleimide, $M_{\mathrm{W}} 2942 \mathrm{~g} / \mathrm{mol}$ ) was purchased from Avanti Polar Lipids Inc. (Alabaster, AL). MicroBCA Protein Assay Kit was from Thermo Scientific (Brebières, 
France). Following materials were used in cell culture and in vitro tests: Dulbecco's Modified Eagle Medium (DMEM) (1 g/L glucose), Hank's Balanced Salt Solution (HBSS), Ham's F12 Nutrient Mixture, N1 Medium Supplement - Sterile-Filtered suitable for neural Cell Cultures, phosphate buffered saline (PBS), fetal bovine serum (FBS), versene (EDTA) and trypsine (BioWhittaker, Verviers, Belgium), antibiotic and antimycotic solution (SigmaAldrich), fluorescence mounting medium (Dako, Glostrup, Denmark), CellTiter 96® AQueous Non-Radioactive Cell Proliferation Assay (MTS; 3-(4,5-dimethylthiazol-2-yl)-5-(3carboxymethoxyphenyl)-2-(4-sulfophenyl)-2H-tetrazolium) (Promega, Charbonnieres, France), mouse anti-human integrin $\alpha_{\mathrm{v}} \beta_{3}$ monoclonal antibody (Millipore, Molsheim, France), mouse isotype control $\mathrm{IgG}_{1}$ (BD Biosciences, Le Pont-de-Claix, France), and polyclonal goat anti-mouse immunoglobulins/FITC Goat F(ab')2 (Dako, Glostrup, Denmark). All other reagents used were of analytical grade.

\section{Methods}

Preparation of ${ }^{99 m}$ Tc-SSS complex

Pertechnetate $\left({ }^{99 \mathrm{~m}} \mathrm{TcO}_{4}{ }^{-}\right)$was obtained from the University Hospital of Angers (CHU Angers, France). The ${ }^{99 \mathrm{~m}}$ Tc-SSS complex (bis (perthiobenzoato) (dithiobenzoato) technetium(III) heterocomplex) was prepared according to the following method [19, 36]: $750 \mathrm{MBq}$ of ${ }^{99} \mathrm{TcO}_{4}{ }^{-}$in $0.5 \mathrm{~mL} 0.9 \% \mathrm{NaCl}$ was added to the formulation kit with a lyophilized mixture containing $30 \mathrm{mg}$ sodium gluconate, $30 \mathrm{mg}$ ascorbic acid, $40 \mathrm{mg}$ potassium oxalate, and $4 \mathrm{mg}$ $\mathrm{SnCl}_{2} \cdot 2 \mathrm{H}_{2} \mathrm{O}$, and the reconstituted solution was mixed for 15 minutes at room temperature. Then, $20 \mathrm{mg}$ of sodium dithiobenzoate ligand (in $0.5 \mathrm{~mL}, \mathrm{pH}$ 7) (Platform of Organic Synthesis, Rennes, France) was added and the mixture was heated at $100{ }^{\circ} \mathrm{C}$ for 30 minutes, which allowed formation of the ${ }^{99 m}$ Tc-SSS complex. Due to its precipitation in aqueous 
media, the complex was extracted with dichloromethane $(1 \mathrm{~mL})$ and washed three times with $1 \mathrm{~mL}$ of deionized water.

\section{Lipid nanocapsule $(L N C)$ preparation and characterization}

Fluorescent DiI-loaded LNC were used for the in vitro uptake studies, confocal microscopy, and MTS cytotoxicity assays whereas radiolabelled ${ }^{99 \mathrm{~m}} \mathrm{Tc}-\mathrm{LNC}$ were used in the in vivo biodistribution studies. Blank LNC were used to assay the efficacy of peptide grafting.

LNC were prepared by the phase inversion method described by Heurtault et al. [9]. Solutol® (282 mg), Lipoid® (25 mg), Labrafac $®(343 \mathrm{mg}), \mathrm{NaCl}(30 \mathrm{mg})$ and water $(987 \mathrm{mg})$ were

mixed and the ${ }^{99 \mathrm{~m}} \mathrm{Tc}-\mathrm{SSS}$ complex in dichloromethane $\left({ }^{99 \mathrm{~m}} \mathrm{Tc}-\mathrm{LNC}\right)$ or DiI in acetone (DiILNC) was added to this mixture. When preparing fluorescent $\mathrm{LNC}$, final concentration of DiI was $3 \mathrm{mmol} / \mathrm{L} /$ total Labrafac ${ }^{\circledR}$ amount used in the formulation. Dichloromethane/acetone was evaporated by heating at $60{ }^{\circ} \mathrm{C}$ for 15 min under stirring. The formulation was heated to $85^{\circ} \mathrm{C}$ at a rate of $5{ }^{\circ} \mathrm{C} / \mathrm{min}$ followed by cooling at the same rate to $65{ }^{\circ} \mathrm{C}$. This cycle was repeated twice. During the last cooling step, at $78{ }^{\circ} \mathrm{C}$ (during the phase inversion zone), the system was diluted with $4.2 \mathrm{~mL}$ cold $\left(4^{\circ} \mathrm{C}\right)$ water leading to formation of stable LNC. The final LNC concentration was $115 \mathrm{mg} / \mathrm{mL}$.

Size distributions and zeta $(\zeta)$ potentials of LNC were determined using Zetasizer ZS (Malvern, Worcestershire, UK). Particle sizing was based on photon correlation spectroscopy (PCS); the results were analyzed by CONTIN algorithm and the size was presented based on the volumetric distribution together with the polydispersity index (PdI). Electrophoretic mobilities were converted to $\zeta$-potential using Smoluchowski's equation. 
cRGD/cRAD peptide grafting on LNC

Initially the individual peptides were grafted on to an amphiphilic molecule, DSPE- $\mathrm{PEG}_{2000^{-}}$ maleimide, using the conjugation chemistry between the thiol-group present on the cyclic structure of the peptide and the malemide [37]. Then, the conjugate was post-inserted in the shell of the LNC [21, 22, 38] (Fig. 1).
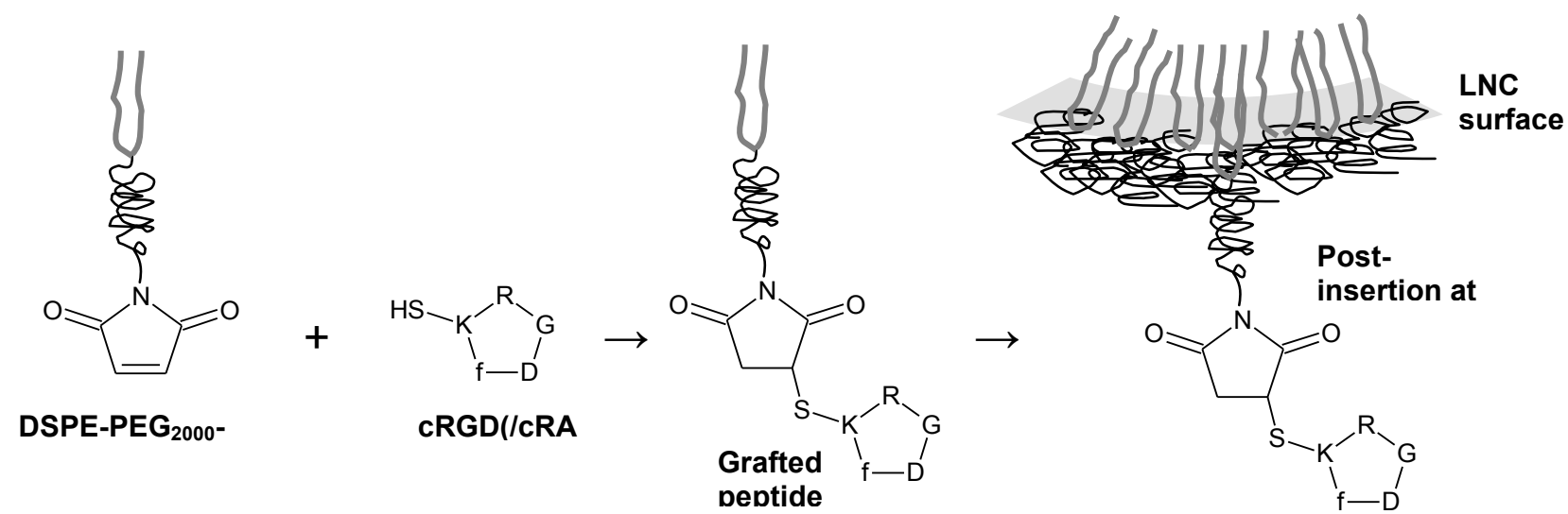

Figure 1. Peptide grafting on LNC. DSPE-PEG2000-maleimide was incubated with cRGD or cRAD peptide which had a modified lysine with a terminal thiol group (-SH). The reaction between the cyclic structure of the maleimide and the thiol group resulted in a grafted peptide. Incubation of this amphiphile grafted peptide with the LNC at elevated temperature allowed the lipophilic moiety, DSPE on the grafted complex, to insert into the LNC shell.

Grafting was performed in $25 \mathrm{mM}$ HEPES buffer containing $1 \mathrm{mM}$ EDTA. pH was adjusted to 7.4 with the help of $\mathrm{NaOH}$, and the buffer was degassed with argon for 30 min before use. cRGD/cRAD was dissolved in the buffer at the concentration of $5 \mathrm{mg} / \mathrm{mL}$. TCEP was diluted to $50 \mathrm{mM}$ with the same buffer. About 1.5 -fold molar excess of TCEP was added to the peptide solution and stirred for $30 \mathrm{~min}$. Meanwhile, DSPE-PEG ${ }_{2000}$-maleimide was dissolved 
in the buffer at the concentration of $12 \mathrm{mg} / \mathrm{mL}$. Then, the DSPE-PEG ${ }_{2000}$-maleimide solution was added dropwise into the peptide/TCEP solution; the final molar ratio of peptide / DSPE$\mathrm{PEG}_{2000}$-maleimide was adjusted to $2: 1$. This solution was stirred gently at room temperature for $2 \mathrm{~h}$ protected from light. Following the amphiphile grafted peptide formation, different LNC, ${ }^{99 \mathrm{~m}} \mathrm{Tc}-\mathrm{LNC}$, or DiI-LNC were added individually and the mixture was stirred for $3 \mathrm{~h}$ at $37{ }^{\circ} \mathrm{C}$. The mass of the LNC added was 4-fold higher than the mass of the peptide/DSPE$\mathrm{PEG}_{2000}$-maleimide conjugate. Finally, the grafted LNC were dialysed for $2 \mathrm{~h}(50 \mathrm{kDa}$ MWCO Spectra/Por membranes, Spectrum Laboratories Inc., Breda, The Netherlands) in excess water. In general, the concentration of the peptide-grafted LNC after the grafting process was about $30 \mathrm{mg} / \mathrm{mL}$.

Peptide grafting efficiency was evaluated by the following procedure: initially the LNC were first post-inserted with an excess of DSPE-PEG ${ }_{2000}$-maleimide $\left(3 \mathrm{~h}, 37{ }^{\circ} \mathrm{C}\right)$. Free DSPE$\mathrm{PEG}_{2000}$-maleimide was then separated from the post-inserted LNC employing a $1.5 \mathrm{~cm} \times 40$ cm Sepharose CL4-B column equilibrated with the HEPES buffer. Turbidimetric measurement at $580 \mathrm{~nm}$ (Multiskan Ascent reader, Thermo Fisher Scientific, Saint Herblain, France) was performed in order to evaluate the LNC-DSPE-PEG 2000 -maleimide concentrations within the collected fractions. Peptides (cRGD/cRAD) were pre-treated with TCEP as described earlier. Peptide solutions were divided in two equal parts: one part was used in the grafting with LNC-DSPE-PEG 2000 -maleimide (room temperature, $2 \mathrm{~h}$, protected from light; theoretical peptide / DSPE- $\mathrm{PEG}_{2000}$-maleimide ratio 2:1), while the other part served as a "free peptide" control (treated with the buffer). Finally, after column separation of both solutions, collected fractions (1 mL, until $85 \mathrm{~mL})$ were analysed with MicroBCA protein assay. Differences in the quantities of the free peptides were used to calculate peptide amounts / LNC. LNC were quantified as described elsewhere [39]. 


\section{Cells}

U87MG, human gliobastoma cell line from American Type Culture Collection (Manassas, VA), was cultured in DMEM supplemented with $1 \%$ glutamine, $10 \%$ FBS, and $1 \%$ antibiotic and antimycotic solution, at $37{ }^{\circ} \mathrm{C}$ in a humidified $95 \%$ air / 5\% $\mathrm{CO}_{2}$ atmosphere. Cell phenotyping is described as Supplementary data.

\section{MTS Assay}

In MTS assay, metabolically active cells convert the MTS reagent into formazan. The quantity of this product formed is directly proportional to the number of living cells and it can be measured spectrophotometrically [40].

MTS assay was performed on a 96-well plate. About 5000 U87MG cells/well were grown in $100 \mu \mathrm{L}$ of the culture medium for $48 \mathrm{~h}$. The cells were then treated with $20 \mu \mathrm{L}$ of different samples (individual peptides, LNC, LNC-cRGD/cRAD) at different concentration ranges.: 0$10 \mu \mathrm{g} / \mathrm{mL}$ for cRGD/cRAD peptides and $0-1.5 \mathrm{mg} / \mathrm{mL}$ for $\mathrm{LNC}$ and $\mathrm{LNC}-\mathrm{cRGD} / \mathrm{cRAD}$. The cells were treated for $1.5 \mathrm{~h}$ at $37^{\circ} \mathrm{C}$ was followed by medium removal and a rinse with HBSS. Then, $120 \mu \mathrm{L}$ of medium containing $20 \mu \mathrm{l}$ of MTS reagent was added to each well and the plates were incubated for $2 \mathrm{~h}$ at $37{ }^{\circ} \mathrm{C}$ protected from light. Finally, the plates were read at 492 nm with Multiskan Ascent reader.

\section{Flow cytometry assay}

Binding and uptake studies were performed on 24-well plates using DiD-loaded LNCs. 20000 cells/well were grown in $500 \mu \mathrm{L}$ of the culture medium for $72 \mathrm{~h}$. The medium was then replaced and $50 \mu \mathrm{L}$ of different $\mathrm{LNC}$ dispersions (LNC, LNC-DSPE-PEG ${ }_{2000}$-maleimide, LNC-cRGD or LNC-cRAD) were added at the concentration of $400 \mu \mathrm{g} / \mathrm{mL}$ on cells followed 
by an incubation for $1 \mathrm{~h}$ at $4{ }^{\circ} \mathrm{C}$ or $37^{\circ} \mathrm{C}$. After the incubation, the media was collected in 1.5 $\mathrm{mL}$ Eppendorf centrifuge tubes. The cells were collected in their respective collection tubes by scrapping in the presence of $200 \mu \mathrm{L}$ of versene solution that facilitates the detachment of cells. The remaining cells were collected with a $200 \mu$ L HBSS wash. The collected cells were washed twice with HBSS and resuspended in PBS containing $0.02 \%$ azide and $0.72 \%$ formaldehyde which was later used in the flow cytometry analysis. A BD FACS Calibur ${ }^{\mathrm{TM}}$ fluorescent-activated flow cytometer and BD CellQuest ${ }^{\mathrm{TM}}$ software (BD-biosciences, Le Pont de Claix, France) were used to perform flow cytometry analysis as described elsewhere [12]. Data were analyzed with WinMDI software.

\section{Confocal microscopy}

About 10000 cells/well (8 well Lab-Tek Chamber Slide, Nunc, Rochester, USA) were grown in $300 \mu \mathrm{L}$ of the culture medium for $72 \mathrm{~h}$. Before incubation with the DiI-loaded LNC, the cells were conditioned for $1 \mathrm{~h}$ with a serum-free medium containing 50\% DMEM, 50\% Ham's F-12, and 1\% N1 medium supplement. The cells were treated with $115 \mu \mathrm{g} / \mathrm{mL}$ of. LNC, LNC-cRGD, or LNC-cRAD using a fresh serum-free media with N1 supplement for $1 \mathrm{~h}$ at $37{ }^{\circ} \mathrm{C}$. After a rinse with HBSS, the cells were fixed with $4 \%$ paraformaldehyde for 10 min at $4{ }^{\circ} \mathrm{C}$. After another HBSS rinse, the support grill of the slide was removed, a drop of fluorescent mounting medium was added to the slide and covered with a coverslip. Confocal microscopy was performed with a FluoView FV300 (Olympus, Paris, France).

\section{In vivo biodistribution study}

24 female NMRI nude mice (4-6 weeks old, JANVIER, Le Genest Saint Isle, France) were used in the study. The animal experiments were performed in agreement with the EEC guidelines and the "Principles of Laboratory Animal Care" (NIH Publication no. 86-23, 
revised 1985), and the experimental protocol was approved by the local ethics committee. Mice were subcutaneously injected with U87MG cells $\left(2 \times 10^{6} /\right.$ mouse $)$ in their left flank. After tumour growth for $\sim 3$ weeks the mice were anesthetized with a mixture of ketamine $(100 \mu \mathrm{g} / \mathrm{g}) /$ medetomidine $(0.2 \mu \mathrm{g} / \mathrm{g})$ by an intraperitoneal injection, and then $200 \mu \mathrm{L}$ of ${ }^{99 m}$ Tc-loaded LNC-cRGD or LNC-cRAD ( $\left.26 \mathrm{MBq}\right)$ were injected intravenously in the tail vein.

To study tissue distribution and pharmacokinetics of LNC, the animals were sacrificed at $1 \mathrm{~h}$, $3 \mathrm{~h}$, and $24 \mathrm{~h}$ after injection ( $\mathrm{n}=4$ at each time point for one type of LNC). The organs and blood were removed and weighed. Activity of each removed organ, blood and rest of the carcass was determined using a gamma counter (Packard Auto-Gamma 5000 series, PerkinElmer Inc., Courtaboeuf, France).

\section{Statistical analysis}

Statistical significance was determined by 2-tailed unpaired Student's $t$-test (when two variables were compared) or by one-way ANOVA with Dunnett's test (when compared to a reference) (Prism, GraphPad Software, Inc., La Jolla, CA). The differences were considered as significant with $p<0.05$.

\section{Results}

\section{LNC preparation and peptide grafting}

Size and $\zeta$-potential of blank LNC as well as peptide-grafted LNC are presented in Table 1. As reported earlier, encapsulation of ${ }^{99 \mathrm{~m}} \mathrm{Tc}$ or DiI did not change these characteristics of the blank LNC (data not shown) as also reported earlier [19, 20]. On the contrary, peptide grafting increased the size of LNC by 11-14 nm while PdIs remained relatively low indicating 
homogeneous size distributions. $\zeta$-Potential of the blank LNC (measured in water) was slightly negative whereas the peptide grafting decreased the $\zeta$-potential to about $-45 \mathrm{mV}$. When measured in physiological PBS, $\zeta$-potential values of the blank LNC remained in the same range $(-2 \mathrm{mV})$ but that of the peptide-grafted LNC approached neutrality: $-6.1 \mathrm{mV}$ for LNC-cRGD and -6.4 mV for LNC-cRAD. Size of LNC post-inserted with DSPE-PEG $2000^{-}$ maleimide without peptide grafting was $3-6 \mathrm{~nm}$ smaller $(p<0.01)$ than the size of the peptide-grafted LNC.

\begin{tabular}{|c|c|c|c|}
\hline & Diameter (nm) & PdI & $\zeta$-Potential $(\mathrm{mV})$ \\
\hline LNC & $48.5 \pm 0.4$ & 0.04 & $-2.5 \pm 0.5$ \\
\hline LNC-DSPE-PEG 2000 -maleimide & $56.3 \pm 0.4$ & 0.10 & $-42.3 \pm 2.1$ \\
\hline LNC-cRGD & $59.8 \pm 2.0$ & 0.14 & $-43.7 \pm 0.5$ \\
\hline LNC-cRAD & $62.0 \pm 1.0$ & 0.14 & $-48.1 \pm 2.0$ \\
\hline
\end{tabular}

Table 1. Size, size distribution (PdI) and $\zeta$-potential of LNC (measured in water).

The quantity of the grafted peptides was evaluated after column separation: unbound peptide amount of LNC-cRGD/cRAD was compared to a same initial quantity of free peptides. The MicroBCA assay of the column fractions revealed $3.7 \mu \mathrm{g}$ of cRGD and $4.0 \mu \mathrm{g}$ of cRAD grafted per mg of LNC, respectively. These values corresponded to about 230 cRGD or 240 cRAD molecules / single LNC. Fractions containing the free peptides were used in the assay instead of the fractions containg LNC-cRGD/cRAD because the other LNC components, besides the peptides, were observed to interfere with the assay. 
MTS assay

RGD-peptides are known to exhibit anti-adhesive and apoptotic properties toward cancer cells [41-43]. Therefore, MTS cell quantification assay was performed in order to evaluate the effects of different treatments, cRGD/cRAD peptides, LNC, or peptide-conjugated LNC, on the viability of U87MG cells (Fig. 2).
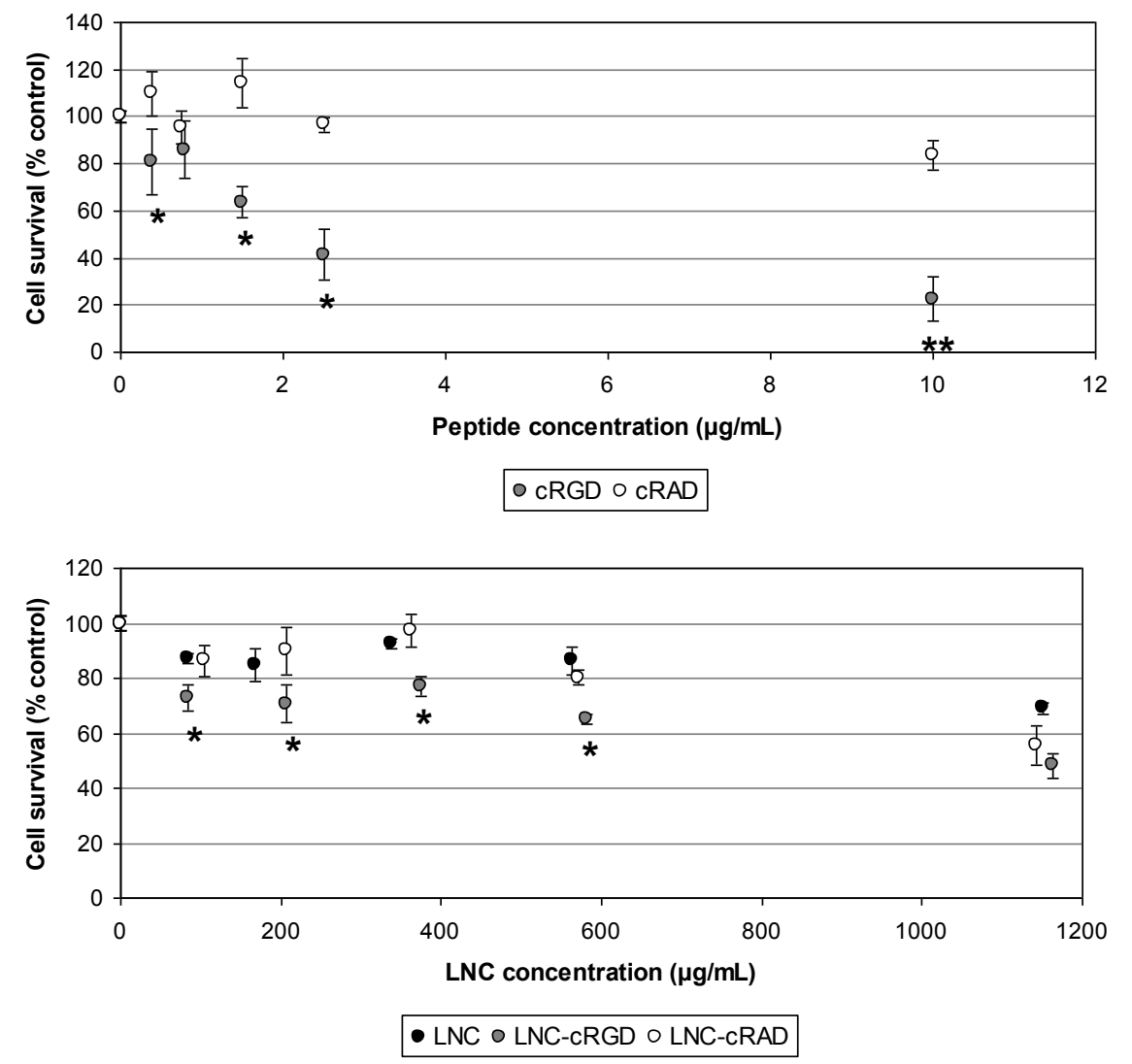

Figure 2. MTS cell quantification assay. Effect of cRGD/cRAD peptides (above), and blank $L N C$ and $L N C-c R A G / c R A D$ (below) on the U87MG viability. $* p<0.05 ; * * p<0.01 ; * * * p$ < 0.001: calculated between cRGD and cRAD or LNC-cRGD vs. LNC and LNC-cRAD.

When the peptides without LNC were tested, cRGD provoked cell loss throughout the studied concentration range (Fig. 3). Quantity of cells remaining attached was $80 \%$ at the lowest tested concentration $(0.39 \mu \mathrm{g} / \mathrm{mL})$ and decreased to about $20 \%$ at the highest concentration tested $(10 \mu \mathrm{g} / \mathrm{mL})$.. Instead, cRAD did not differ from the control $(0 \mu \mathrm{g} / \mathrm{mL})$, except at the highest tested concentration $(10 \mu \mathrm{g} / \mathrm{mL})$, where the cell attachment was a bit above $80 \%$. All 
the three tested LNC types, without or with peptides, induced cell loss in a concentration dependant manner which was lower than the free peptide treatment. Cells remaining attached at the highest particle concentration tested $(\sim 1150 \mu \mathrm{g} / \mathrm{mL})$ was about 50-70\%. Although significant, the difference among the different LNC treatments, LNC/LNC-cRAD and LNCcRGD, were not as well pronounced as that of pure peptides.

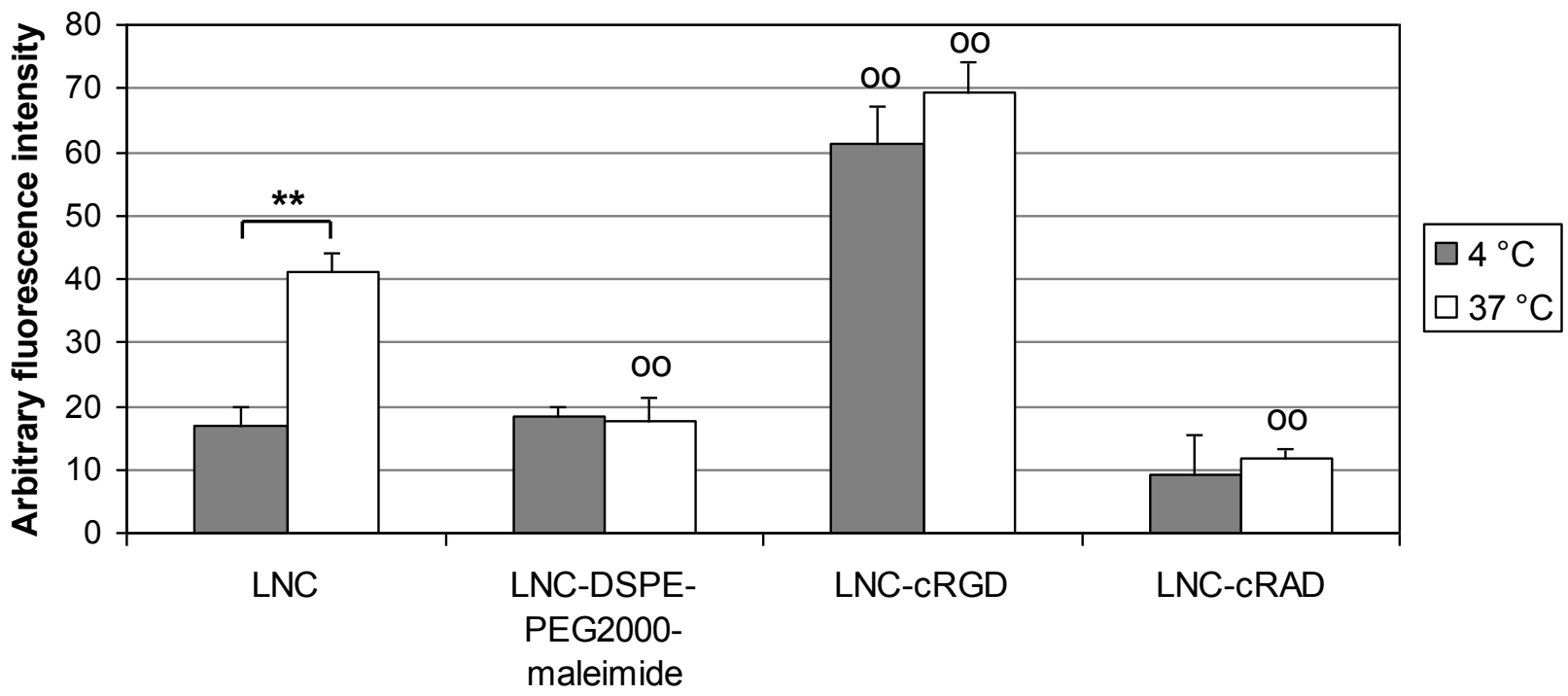

Figure 3. Binding $\left(4{ }^{\circ} \mathrm{C}\right)$ and uptake $\left(37^{\circ} \mathrm{C}\right)$ of $L N C$, LNC-DSPE-PEG 2000 -maleimide, and $L N C-c R G D / c R A D$ by U87MG cells. ${ }^{* *} p<0.01: L N C 4{ }^{\circ} \mathrm{C}$ vs. $L N C 37^{\circ} \mathrm{C}$; ${ }^{o o} p<0.01 \mathrm{vs}$. corresponding $L N C 4 / 37^{\circ} \mathrm{C}$ value.

\section{Cell binding and internalization}

Targeting properties of different LNC were evaluated in vitro by flow cytometry and confocal microscopy. Capacity of LNC, LNC-DSPE-PEG 2000 -maleimide, LNC-cRGD and LNC-cRAD to associate with U87MG cells (binding and uptake) was first studied by flow cytometry (Fig. 3). To discriminate active versus passive mechanisms, experiments were realised at $4{ }^{\circ} \mathrm{C}$ and $37{ }^{\circ} \mathrm{C}$. Indeed, lowering temperature usually turned off global cell metabolic activity, among which mechanisms of active uptake. However, binding was not avoided. With LNC, significant difference was observed between $4{ }^{\circ} \mathrm{C}$ and $37{ }^{\circ} \mathrm{C}$ with about 2.4 times more LNC 
combined with cells at $37{ }^{\circ} \mathrm{C}$ than at $4{ }^{\circ} \mathrm{C}$. In contrast, with LNC-DSPE-PEG 2000 -maleimide, LNC-cRGD and LNC-cRAD, amount of LNC combined with cells was found to be the same at $4{ }^{\circ} \mathrm{C}$ and $37{ }^{\circ} \mathrm{C}$, thus indicating that saturation modalities of recognition sites and routing within U87MG cells were distinct between functionalized and blank LNC. Binding and internalization of the negative control LNC-cRAD at $4{ }^{\circ} \mathrm{C}$ and $37{ }^{\circ} \mathrm{C}$ were about twice lower than the quantities observed for LNC or LNC-DSPE-PEG ${ }_{2000}$-maleimide whereas LNC-cRGD association with cells at $4{ }^{\circ} \mathrm{C}$ and $37{ }^{\circ} \mathrm{C}$ was about 3.5 times higher when compared to LNC and LNC-DSPE-PEG 2000 -maleimide and 6.7 times higher than LNC-cRAD thus supporting an interaction of LNC-cRGD with the U87MG cells governed by the cRGD functionalization of the particles.

Confocal microscopy was applied in order to better differentiate the binding and internalization phenomena. U87MG cells were incubated for $1 \mathrm{~h}$ at $37{ }^{\circ} \mathrm{C}$ with the different LNC. The overlay fluoresecence images of LNC and LNC-cRGD treatments showed internalization of the particles as observed by the presence of fluorescent LNC mainly in the cytoplasm (excluding the nuclea which were less fluorescent) (Fig. 4). Instead, the fluorescence staining of the LNC-cRAD-treated cells was weak.

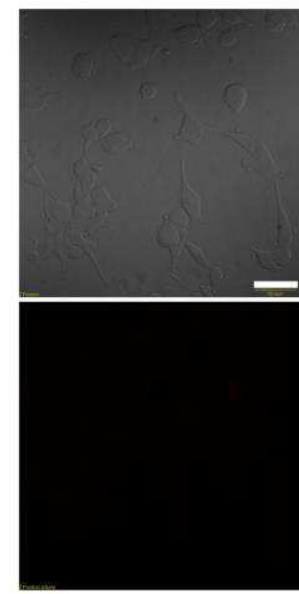

Control

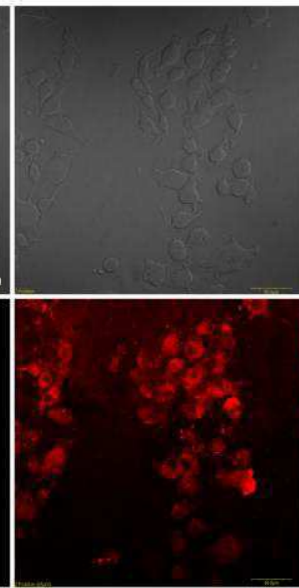

LNC

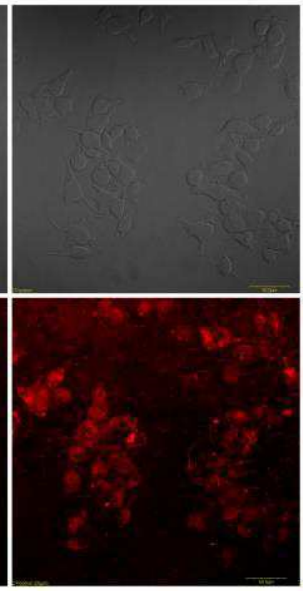

LNC-CRGD

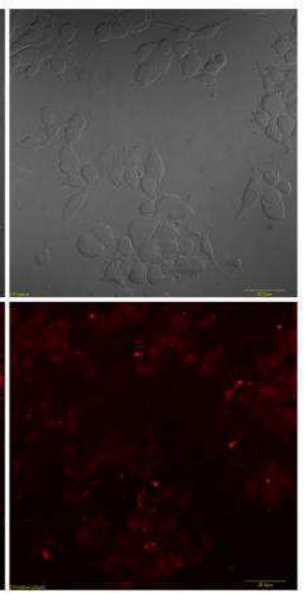

LNC-CRAD

Figure 4. Uptake and binding of $L N C, L N C$-cRGD, and LNC-cRAD by U87MG cells. Confocal microscopy images of U87MG cells alone (control) and cells treated with the different LNC for $1 \mathrm{~h}$ at $37{ }^{\circ} \mathrm{C}$. Above: Nomarski images; below: overlay images from eight layers (total scanned thickness $8 \mu \mathrm{m}$ ). Bar $=50 \mu \mathrm{m}$. 
The in vivo behaviour of the peptide-grafted LNC was studied after their intravenous injection in the tail vein of nude mice bearing subcutaneous U87MG xenograft. Determination of radioactivity of each organ and blood after the sacrifice of animals at different time points allowed analysis of tissue distribution and blood pharmacokinetics (Fig. 5).

\section{LNC-CRGD}

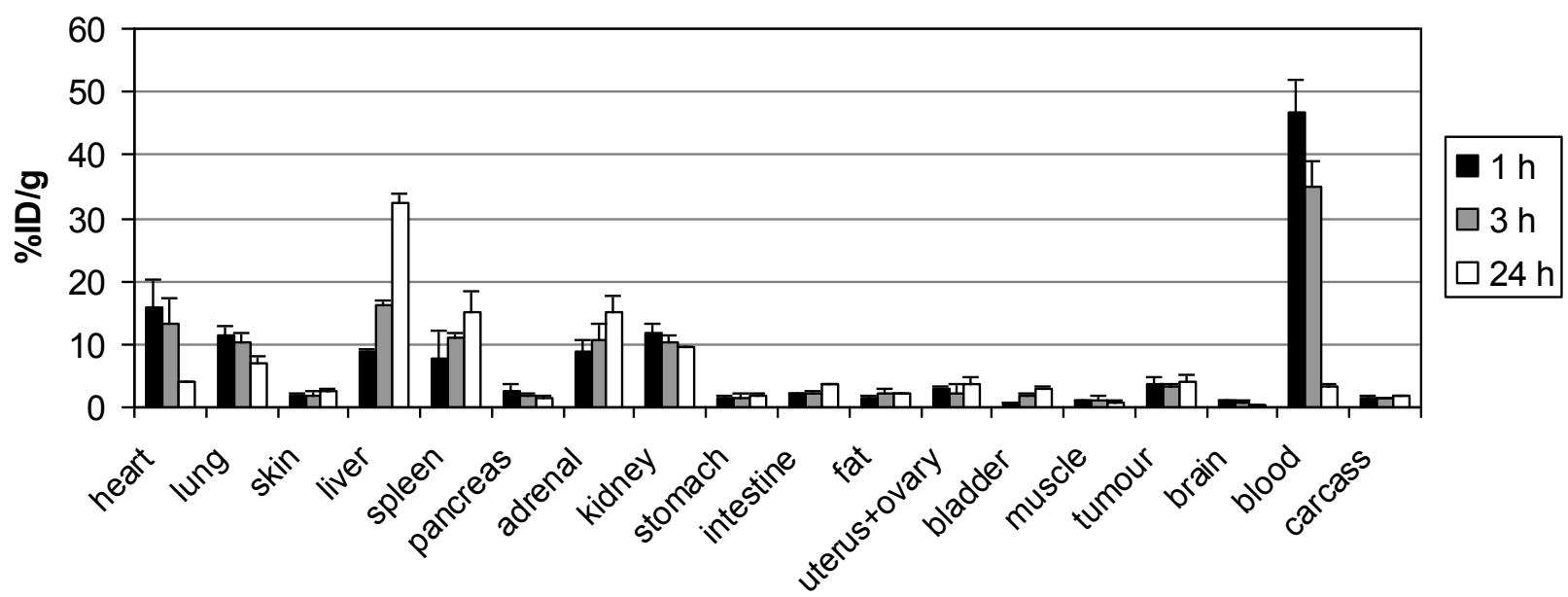

LNC-CRAD

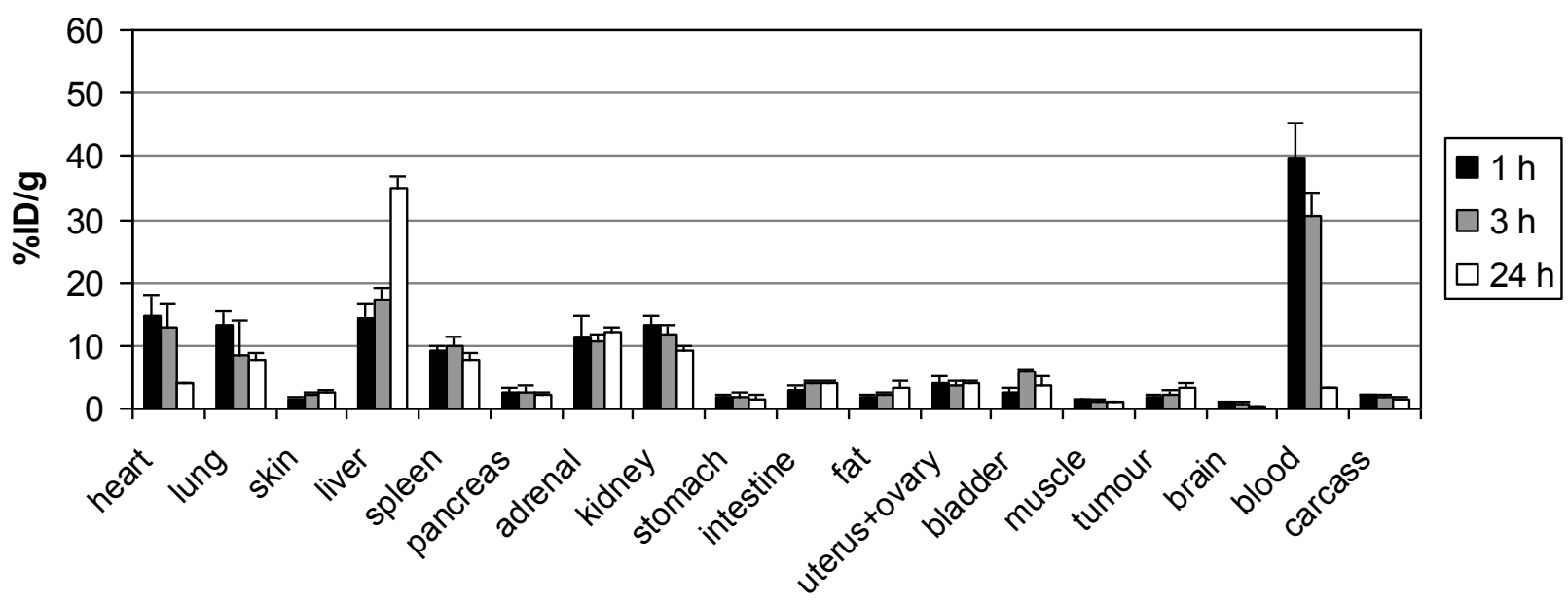

Figure 5. Tissue distribution and blood kinetics of LNC-cRGD and LNC-cRAD as a function of time.

Similar distribution tendency was observed for both types of the peptide grafted LNC in the RES (reticuloendothelial system) organs: the accumulation in liver increased with time whereas in spleen it remained almost constant at the observed time points. The percentage of LNC-cRAD was higher in the liver compared to the percentage of LNC-cRGD $(14.4 \pm 2.1 \%$ 
vs. $8.9 \pm 0.5 \% ; p<0.01)$ at $1 \mathrm{~h}$. Inversely, more LNC-cRGD compared to LNC-cRAD was found in spleen at $24 \mathrm{~h}(15.1 \pm 3.3 \%$ vs. $7.9 \pm 1.0 \% ; p<0.01)$. Otherwise, the radioactivities found in all the other dissected organs were in the same range for both the LNC throughout the studied time scale. There were minor differences in the circulation time of the LNC tested, however the differences were not statistically significant: $46.7 \pm 5.3 \%$ and $39.8 \pm 5.6 \%$ at $1 \mathrm{~h}$, $35.0 \pm 4.0 \%$ and $30.7 \pm 3.5 \%$ at $3 \mathrm{~h}$, and $3.2 \pm 0.5 \%$ and $3.3 \pm 0.1 \%$ at 24 for LNC-cRGD and LNC-cRAD, respectively. Radioactivity levels observed in tumours were the following: ID/g values $3.6 \pm 1.1 \%, 3.5 \pm 0.4 \%$ and $4.0 \pm 1.3 \%$ (LNC-cRGD) and $1.8 \pm 0.4 \%, 2.1 \pm 0.8 \%$ and $3.4 \pm 0.6 \%$ (LNC-cRAD) at 1,3 and $24 \mathrm{~h}$, respectively. Radioactivity in the tumour was significantly higher within LNC-cRGD treated mice at 1-3 h (Fig. 6). At $24 \mathrm{~h}$, accumulation of the both types of particles (LNC-cRGD and LNC-cRAD) was similar.

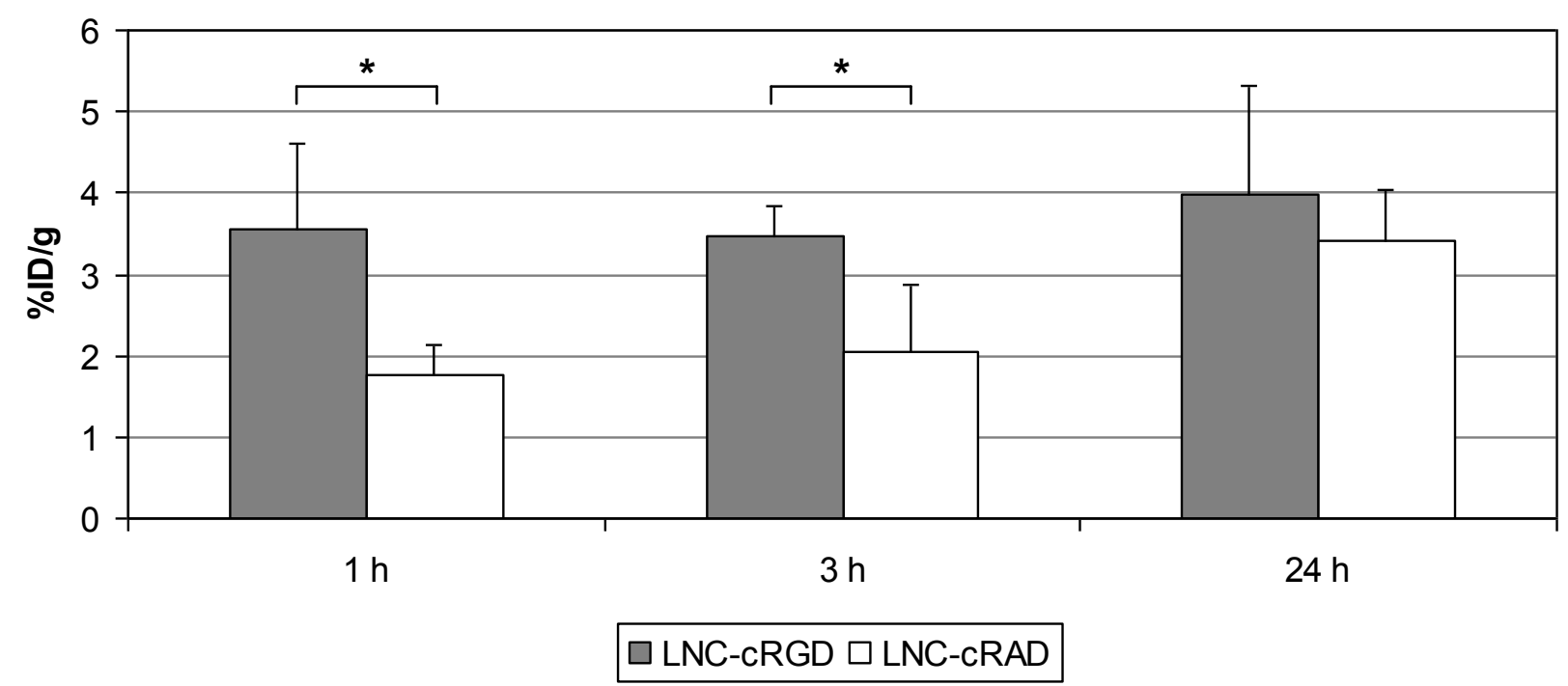

Figure 6. Tumour uptake of LNC-cRGD and LNC-cRAD as a function of time. ${ }^{*} p<0.05$. 


\section{Discussion}

Previously, LNC have been used as templates for the attachment of whole antibodies or their Fab' fragments either to target transferrin receptors expressed on the cerebral endothelium $[21,44]$ or other markers associated to cancer stem cells [22]. Similar to the current study, these targeting moieties were also thiolated, and grafted on DSPE-PEG 2000 -maleimide amphiphilic lipids which were then post-inserted into the LNC shell. In the current study, increase of the LNC size after incorporation of the peptides was a proof of successful surface modification. Also, the size difference between the peptide-grafted LNC and the LNC postinserted with DSPE-PEG 2000 -maleimide indicated attachment of the peptides. Slightly negative $\zeta$-potential of blank LNC is assumed to originate from PEG groups at the surface forming dipoles that are able to interact with counterions or water dipoles [45]. When amphiphilic molecules were post-inserted in the LNC shell, in this case grafted with peptides, particles with a higher density of dipolar moments confined in a small volume are obtained [38]. As a result, $\zeta$-potential values decreased with the increase of electronic density. However, the overall charge density on the LNC surface and the nature of the charges (dipoles) seemed not to be important enough to prevent neutralization of the charges when these LNC were dispersed in a medium of higher ionic strength (PBS). Indeed, post-insertion into LNC yields typically about 5-15 mol-\% of the inserted molecules of the total material forming the shell (Solutol®, Lipoid $\AA$ ) [44]. Therefore, it can be assumed that the grafting did not result in highly charged LNC under physiological conditions; otherwise the blood circulation time could thus be reduced.

Quantification of the grafted cRGD/cRAD peptides by the MicroBCA assay estimated that approximately 230-240 peptides could be found on the surface of a single LNC. These quantities were slightly higher than the amounts of monoclonal antibodies ( 30-60/LNC) that 
could be grafted on the surface of LNCs in the previous studies [22, 44]. This might result from less steric hindrance offered by the smaller cRGD/cRAD molecules favouring more advantageous coupling conditions and accessibility to ligands. Coupling of RGD peptides to other types of nanoparticles have resulted similarly e.g. in 200-400 RGD peptides / 130-nm polymer nanoparticle [46], and in 300 RGD/RAD peptides / 100-nm liposome [32]. Although a dose-response study might be useful to determine the exact benefit of conjugation of large versus low number of cRGD motifs per particle in vitro and in vivo, previous works have already established that higher affinity and internalization are facilitated by multivalent RGD-ligands [47]. Here, LNC represent a useful exemple of that.

In angiogenesis, the endothelial cells bind to extracellular matrix components via $\alpha_{v} \beta_{3}$ integrins [25]. Inhibition of this interaction is capable of inducing apoptosis of the proliferating angiogenic cells [43]. RGD peptides were reported to have the ability to detach cells from their culture support and this anti-adhesive property was demonstrated on BT-20 (human breast carcinoma), HUVEC (human umbilical vein endothelial cells), and U87MG cell lines [41-43]. A similar observation was made in this study with U87MG cells (Fig. 2). cRGD peptide treatment detached cells from their support while no effect was observed with the negative control cRAD peptide. Instead, cRGD peptides grafted on LNCs had diminished ability to detach cells although remaining statistically significant over other LNC treatments. Cell detachment observed at high concentrations of LNC, LNC-cRGD and LNC-cRAD could mainly result from non-specific interactions between the LNC surfactant and the cell membranes as previously established [48].

However, the magnitude of the anti-adhesive effect does not always correlate with the internalization capacity of the targeted nanoparticles: strong anti-adhesion might accompany poor internalization and vice versa [42]. There were significant differences in the observed cellular fluorescence intensity between the cells incubated with $\mathrm{LNC}$ at $4{ }^{\circ} \mathrm{C}$ or $37^{\circ} \mathrm{C}$ (Fig. 3). 
This observation is reminiscent of the previously described active internalization of LNC at $37{ }^{\circ} \mathrm{C}$ [48]. Instead, no such differences were observed when cells were treated with LNCDSPE-PEG 2000 -maleimide or LNC-cRAD. Obviously, the negative surface charge provided by DSPE-PEG 2000 -maleimide inhibited $\mathrm{LNC}$ internalization, but it did not affect the binding and remained similar to that of blank LNC, while the binding was also comparatively a bit lower for the LNC-cRAD. Significantly higher binding of LNC-cRGD supported the interaction between the cRGD peptide and $\alpha_{\mathrm{v}} \beta_{3}$ integrins of the U87MG cell surface. According to the flow cytometry results, association of LNC-cRGD to U87MG cells was not higher when active processes were inhibited $\left(4^{\circ} \mathrm{C} v s .37^{\circ} \mathrm{C}\right)$ thus indicating the involvement of saturating mechanisms of binding and uptake of LNC-cRGD within those cells.

Comparable results were obtained when cRGD-lipid nanoparticles that are structurally analogical to LNC were used to target HEK293( $\beta 3)$ cells [34]: FACS analysis revealed equal fluorescence intensity after incubation at $4{ }^{\circ} \mathrm{C}$ and $37^{\circ} \mathrm{C}$. However, fluorescence microscopy images proposed that at $37{ }^{\circ} \mathrm{C}$, endosome-like patterns were observed indicating particle internalization. To get a better insight about internalization, confocal microscopy was applied to visualize U87MG cells after incubation at $37{ }^{\circ} \mathrm{C}$ with the different LNC (Fig. 4). These results revealed internalization of LNC and LNC-cRGD. In the case of LNC-cRGD, it seemed that a binding saturation limit was reached and no further binding sites were regenerated at the concentration tested. Otherwise, the difference between binding $\left(4^{\circ} \mathrm{C}\right)$ and internalization $(37$ $\left.{ }^{\circ} \mathrm{C}\right)$ of LNC-cRGD would have been greater.

Without a protective coating like PEGylation intravenously administered nanoparticles are quickly taken up by the macrophages of the mononuclear phagocyte system (MPS) and, thus, can be localized in the RES organs such as liver, spleen and lungs [49]. Surface of LNC contains PEG chains and therefore these nanocarriers are known to avoid defence mechanisms of the body to some extent [39]. Despite peptide grafting, more than $30 \%$ of the 
injected dose was found in the blood up to $3 \mathrm{~h}$ without major accumulation in the RES organs indicating longer circulation time (Fig. 5). At $24 \mathrm{~h}$, the LNC had disappeared from the blood and were being eliminated by the liver as seen by increased accumulation in that organ. This kind of pharmacokinetic profile might be advantageous as the current opinion prefers nanoparticle elimination in a reasonable time rather than extensively prolonged blood circulation profiles [50]. Radioactivity levels in kidneys ( 10\%, decrease with time) indicated also LNC accumulation: $75 \pm 25 \mathrm{~nm}$ PEGylated gold nanoparticles are reported to enter the fenestrated glomerular endothelia (80-100 $\mathrm{nm}$ pores) and accumulate in the kidney mesangium [51]. Blank LNC (50 nm) presented blood distribution kinetics and accumulation in different organs comparable to these peptide-grafted LNC which proved that the peptide grafting did not modify overall biodistribution profile of LNC [52]. Blank LNC accumulated in the main RES organs similarly: \% ID/g in the liver increased from $\sim 15 \%$ (1.5 h) to $40 \%$ (24 h) and remained around $10 \%$ in the spleen during the same time range. $\% \mathrm{ID} / \mathrm{g}$ in the blood circulation decreased from $\sim 30 \%(1.5 \mathrm{~h})$ to $\sim 2 \%(24 \mathrm{~h})$.

As there was no difference in the blood kinetics and general biodistribution found between the two peptide grafted LNC, the higher retention of LNC-cRGD in the tumour in the initial few hours can be principally attributed to active targeting achieved by the interaction between cRGD and $\alpha_{v} \beta_{3}$ integrins. Taking into account the long blood circulation time of the tested LNC, increased tumoral accumulation of the negative control LNC-cRAD with time supported passive targeting by the EPR (enhanced permeation and retention) effect [53]. At $24 \mathrm{~h}$, accumulation in the tumour mass had probably reduced the cRGD-integrin retention effect (no difference between LNC-cRGD and LNC-cRAD). Similarly, no difference in tumoral accumulation was found between RGD and RAD liposomes (100 nm) at $24 \mathrm{~h}$ (only evaluated time point in that study) [32]. In general, \% ID/g in tumour observed in this study were in the same level ( $\sim 5 \%$ or less) as e.g with PLA-PEO-RGD micelles [54], RGD 
liposomes [32], or cRGD monomer [55]. Overall, cumulative exposure of tumours by LNC (i.e. radioactivity in this case) was significantly higher with LNC-cRGD compared to LNCcRAD.

As mentioned in Introduction, the radioactivity gradient created by locoregional administration of ${ }^{188} \mathrm{Re}-\mathrm{LNC}$ showed to be the major determinant for an efficient treatment of rat glioma [18]. In the present study, the fact that we can now focus the radioactive material on $\alpha_{v} \beta_{3}$ expressing cells will also affect the resulting gradient of activity. As such, it has been demonstrated that $\alpha_{v} \beta_{3}$ is expressed not only by glioma cells but also by microvasculature of the tumour thus affecting glioma cell responses to radiotherapy [56]. In this context, Cilengitide (a cRGD derivative) has been investigated as an adjuvant treatment to reinforce external beam radiation [57]. Therefore, regarding the targeted therapy and the internal irradiation, the nanocarrier we have here developed could combine the action on $\alpha_{\mathrm{v}} \beta_{3}$ integrins while also carrying the radiopharmaceutics. However, it should be noted that, because of the minor overall quantity of LNC accumulated in the tumour, internal radiotherapy is not rational by intravenous injections. This hypothesis is worth investigating further using local administration of ${ }^{188}$ Re-LNC-cRGD by convection enhanced delivery as ${ }^{99 \mathrm{~m}} \mathrm{Tc}$ and ${ }^{188} \mathrm{Re}$ in LNC are interchangeable [19].

\section{Conclusions}

In vitro and in vivo performances of cRGD peptide-grafted LNC were assessed in this study. Peptides grafted on amphiphilic molecules could be successfully inserted on the surface of semi-solid LNC. The LNC-cRGD bound efficiently to the $\alpha_{v} \beta_{3}$ integrins expressed by the U87MG glioma cells followed by effective particle internalization. In mice after intravenous administration, accumulation of LNC-cRGD in subcutaneous tumour was significantly higher 
compared to the negative control LNC-cRAD. Based on these results, LNC-cRGD revealed to be promising, tumour-targetable nanocarriers. As lipophilic drug molecules or radioactive complexes can be readily encapsulated in LNC, LNC-cRGD could be used in systemic or local tumour drug targeting or to enhance the specificity of locoregional/internal radiotherapy.

\section{Acknowledgements}

Service Commun de Cytométrie d'Analyses Nucléotidiques (SCCAN) and Service Commun d'Imageries et d'Analyses Microscopiques (SCIAM) (Angers, France) are acknowledged for technical assistance. This work was financially supported by the French National Research Agency (ANR) in the frame of its programme in Nanosciences and Nanotechnologies (CALIF project no. ANR-08-NANO-006), and by Ligue Contre le Cancer - Comité Départemental du Maine et Loire (Equipe Labellisée Ligue Nationale Contre le Cancer 2012), France. 


\section{References}

[1] O.C. Farokhzad, R. Langer, Impact of nanotechnology on drug delivery, ACS Nano 3 (2009) 16-20.

[2] S. Hirsjärvi, C. Passirani, J.-P. Benoit, Passive and active tumour targeting with nanocarriers, Current Drug Discovery Technologies 8 (2011) 188-196.

[3] M.M. Gottesman, T. Fojo, S.E. Bates, Multidrug resistance in cancer: role of ATPdependent transporters, Nat Rev Cancer 2 (2002) 48-58.

[4] T. Reya, S.J. Morrison, M.F. Clarke, I.L. Weissman, Stem cells, cancer, and cancer stem cells, Nature 414 (2001) 105-111.

[5] S. Bao, Q. Wu, R.E. McLendon, Y. Hao, Q. Shi, A.B. Hjelmeland, M.W. Dewhirst, D.D. Bigner, J.N. Rich, Glioma stem cells promote radioresistance by preferential activation of the DNA damage response, Nature 444 (2006) 756-760.

[6] V.P. Torchilin, Recent advances with liposomes as pharmaceutical carriers, Nat Rev Drug Discov 4 (2005) 145-160.

[7] A. Kumari, S.K. Yadav, S.C. Yadav, Biodegradable polymeric nanoparticles based drug delivery systems, Colloid Surf B 75 (2010) 1-18.

[8] B. Heurtault, P. Saulnier, B. Pech, J.-E. Proust, J.-P. Benoit, A novel phase inversionbased process for the preparation of lipid nanocarriers, Pharmaceutical Research 19 (2002) 875-880.

[9] B. Heurtault, P. Saulnier, B. Pech, M.-C. Venier-Julienne, J.-E. Proust, R. Phan-TanLuu, J.-P. Benoit, The influence of lipid nanocapsule composition on their size distribution, Eur J Pharm Sci 18 (2003) 55-61. 
[10] S. Peltier, J.-M. Oger, F. Lagarce, W. Couet, J.-P. Benoit, Enhanced oral paclitaxel bioavailability after administration of paclitaxel-loaded lipid nanocapsules, Pharmaceutical Research 23 (2006) 1243-1250.

[11] F. Lacoeuille, F. Hindré, F. Moal, J. Roux, C. Passirani, O. Couturier, P. Cales, J.J. Le Jeune, A. Lamprecht, J.P. Benoit, In vivo evaluation of lipid nanocapsules as a promising colloidal carrier for paclitaxel, Int J Pharm 344 (2007) 143-149.

[12] E. Garcion, A. Lamprecht, B. Heurtault, A. Paillard, A. Aubert-Pouessel, B. Denizot, P. Menei, J.P. Benoit, A new generation of anticancer, drug-loaded, colloidal vectors reverses multidrug resistance in glioma and reduces tumor progression in rats, Mol Cancer Ther 5 (2006) 1710-1722.

[13] M. Weyland, F. Manero, A. Paillard, D. Grée, G. Viault, D. Jarnet, P. Menei, P. Juin, I. Chourpa, J.P. Benoit, R. Grée, E. Garcion, Mitochondrial targeting by use of lipid nanocapsules loaded with SV30, an analogue of the small-molecule Bcl-2 inhibitor HA14-1, J Control Release 151 (2011) 74-82.

[14] A. Lamprecht, J.-L. Saumet, J. Roux, J.-P. Benoit, Lipid nanocarriers as drug delivery system for ibuprofen in pain treatment, Int J Pharm 278 (2004) 407-414.

[15] M. Morille, C. Passirani, S. Dufort, G. Bastiat, B. Pitard, J.-L. Coll, J.-P. Benoit, Tumor transfection after systemic injection of DNA lipid nanocapsules, Biomaterials 32 (2011) 2327-2333.

[16] C. Vanpouille-Box, F. Lacoeuille, J. Roux, C. Aubé, E. Garcion, N. Lepareur, F. Oberti, F. Bouchet, N. Noiret, E. Garin, J.-P. Benoit, O. Couturier, F. Hindré, Lipid nanocapsules loaded with rhenium-188 reduce tumor progression in a rat hepatocellular carcinoma model, PLoS ONE 6 (2011) e16926.

[17] E. Allard, F. Hindre, C. Passirani, L. Lemaire, N. Lepareur, N. Noiret, P. Menei, J.P. Benoit, Re-188-loaded lipid nanocapsules as a promising radiopharmaceutical carrier 
for internal radiotherapy of malignant gliomas, European Journal of Nuclear Medicine and Molecular Imaging 35 (2008) 1838-1846.

[18] C. Vanpouille-Box, F. Lacoeuille, C. Belloche, N. Lepareur, L. Lemaire, J.-J. LeJeune, J.-P. Benoit, P. Menei, O.F. Couturier, E. Garcion, F. Hindré, Tumor eradication in rat glioma and bypass of immunosuppressive barriers using internal radiation with 188Re-lipid nanocapsules, Biomaterials 32 (2011) 6781-6790.

[19] S. Ballot, N. Noiret, F. Hindré, B. Denizot, E. Garin, H. Rajerison, J.-P. Benoit, ${ }^{99 \mathrm{~m}} \mathrm{Tc} /{ }^{188} \mathrm{Re}$-labelled lipid nanocapsules as promising radiotracers for imaging and therapy: Formulation and biodistribution, European Journal of Nuclear Medicine and Molecular Imaging 33 (2006) 602-607.

[20] M. Morille, T. Montier, P. Legras, N. Carmoy, P. Brodin, B. Pitard, J.-P. Benoit, C. Passirani, Long-circulating DNA lipid nanocapsules as new vector for passive tumor targeting, Biomaterials 31 (2010) 321-329.

[21] A. Béduneau, F. Hindré, A. Clavreul, J.-C. Leroux, P. Saulnier, J.-P. Benoit, Brain targeting using novel lipid nanovectors, J Control Release 126 (2008) 44-49.

[22] E. Bourseau-Guilmain, J. Béjaud, A. Griveau, N. Lautram, F. Hindré, M. Weyland, J.P. Benoit, E. Garcion, Development and characterization of immuno-nanocarriers targeting the cancer stem cell marker AC133, Int J Pharm 423 (2012) 93-101.

[23] R. Misra, S. Acharya, S.K. Sahoo, Cancer nanotechnology: application of nanotechnology in cancer therapy, Drug Discov Today 15 (2010) 842-850.

[24] J.D. Byrne, T. Betancourt, L. Brannon-Peppas, Active targeting schemes for nanoparticle systems in cancer therapeutics, Adv Drug Deliv Rev 60 (2008) 16151626.

[25] J.S. Desgrosellier, D.A. Cheresh, Integrins in cancer: biological implications and therapeutic opportunities, Nat Rev Cancer 10 (2010) 9-22. 
[26] E. Koivunen, B.C. Wang, E. Ruoslahti, Phage libraries displaying cyclic-peptides with different ring sizes - ligand specificities of the RGD-directed integrins, BioTechnology 13 (1995) 265-270.

[27] W. Arap, R. Pasqualini, E. Ruoslahti, Cancer treatment by targeted drug delivery to tumor vasculature in a mouse model, Science 279 (1998) 377-380.

[28] J.D. Hood, M. Bednarski, R. Frausto, S. Guccione, R.A. Reisfeld, R. Xiang, D.A. Cheresh, Tumor regression by targeted gene delivery to the neovasculature, Science 296 (2002) 2404-2407.

[29] E.A. Murphy, B.K. Majeti, L.A. Barnes, M. Makale, S.M. Weis, K. Lutu-Fuga, W. Wrasidlo, D.A. Cheresh, Nanoparticle-mediated drug delivery to tumor vasculature suppresses metastasis, PNAS 105 (2008) 9343-9348.

[30] K.N. Sugahara, T. Teesalu, P.P. Karmali, V.R. Kotamraju, L. Agemy, O.M. Girard, D. Hanahan, R.F. Mattrey, E. Ruoslahti, Tissue-penetrating delivery of compounds and nanoparticles into tumors, Cancer cell 16 (2009) 510-520.

[31] X.-B. Xiong, Y. Huang, W.-L. Lu, X. Zhang, H. Zhang, T. Nagai, Q. Zhang, Intracellular delivery of doxorubicin with RGD-modified sterically stabilized liposomes for an improved antitumor efficacy: In vitro and in vivo, J Pharm Sci 94 (2005) 1782-1793.

[32] R.M. Schiffelers, G.A. Koning, T.L.M. ten Hagen, M.H.A.M. Fens, A.J. Schraa, A.P.C.A. Janssen, R.J. Kok, G. Molema, G. Storm, Anti-tumor efficacy of tumor vasculature-targeted liposomal doxorubicin, J Control Release 91 (2003) 115-122.

[33] F. Danhier, B. Vroman, N. Lecouturier, N. Crokart, V. Pourcelle, H. Freichels, C. Jérôme, J. Marchand-Brynaert, O. Feron, V. Préat, Targeting of tumor endothelium by RGD-grafted PLGA-nanoparticles loaded with paclitaxel, J Control Release 140 (2009) 166-173. 
[34] M. Goutayer, S. Dufort, V. Josserand, A. Royère, E. Heinrich, F. Vinet, J. Bibette, J.L. Coll, I. Texier, Tumor targeting of functionalized lipid nanoparticles: Assessment by in vivo fluorescence imaging, Eur J Pharm Biopharm 75 (2010) 137-147.

[35] L. Bello, M. Francolini, P. Marthyn, J. Zhang, R.S. Carroll, D.C. Nikas, J.F. Strasser, R. Villani, D.A. Cheresh, P. McL. Black, $\alpha_{\mathrm{v}} \beta_{3}$ and $\alpha_{\mathrm{v}} \beta_{5}$ integrin expression in glioma periphery, Neurosurgery 49 (2001) 380-390.

[36] F. Mévellec, F. Tisato, F. Refosco, A. Roucoux, N. Noiret, H. Patin, G. Bandoli, Synthesis and characterization of the "sulfur-rich" bis (perthiobenzoato) (dithiobenzoato) technetium (III) heterocomplex, Inorg Chem 41 (2002) 598-601.

[37] M. Brinkley, A brief survey of methods for preparing protein conjugates with dyes, haptens, and cross-linking reagents, Bioconjugate Chem 3 (1992) 2-13.

[38] T. Perrier, P. Saulnier, F. Fouchet, N. Lautram, J.-P. Benoit, Post-insertion into lipid nanocapsules (LNCs): From experimental aspects to mechanisms, Int J Pharm 396 (2010) 204-209.

[39] A. Vonarbourg, C. Passirani, P. Saulnier, P. Simard, J.-C. Leroux, J.P. Benoit, Evaluation of pegylated lipid nanocapsules versus complement system activation and macrophage uptake, Journal of Biomedical Materials Research Part A 78A (2006) 620-628.

[40] A.H. Cory, T.C. Owen, J.A. Barltrop, J.G. Cory, Use of an aqueous soluble tetrazolium formazan assay for cell-growth assays in culture, Cancer Comm 3 (1991) 207-212.

[41] R.J. Kok, A.J. Schraa, E.J. Bos, H.E. Moorlag, S.A. Ásgeirsdóttir, M. Everts, D.K.F. Meijer, G. Molema, Preparation and functional evaluation of RGD-modified proteins as $\alpha_{v} \beta_{3}$ integrin directed therapeutics, Bioconjugate Chem 13 (2001) 128-135. 
[42] X. Montet, M. Funovics, K. Montet-Abou, R. Weissleder, L. Josephson, Multivalent effects of RGD peptides obtained by nanoparticle display, J Med Chem 49 (2006) 6087-6093.

[43] T. Taga, A. Suzuki, I. Gonzalez-Gomez, F.H. Gilles, M. Stins, H. Shimada, L. Barsky, K.I. Weinberg, W.E. Laug, $\alpha_{v}$-Integrin antagonist EMD 121974 induces apoptosis in brain tumor cells growing on vitronectin and tenascin, Int J Cancer 98 (2002) 690-697.

[44] A. Béduneau, P. Saulnier, F. Hindré, A. Clavreul, J.-C. Leroux, J.-P. Benoit, Design of targeted lipid nanocapsules by conjugation of whole antibodies and antibody Fab' fragments, Biomaterials 28 (2007) 4978-4990.

[45] A. Vonarbourg, P. Saulnier, C. Passirani, J.-P. Benoit, Electrokinetic properties of noncharged lipid nanocapsules: Influence of the dipolar distribution at the interface, ELECTROPHORESIS 26 (2005) 2066-2075.

[46] J. Lu, M. Shi, M.S. Shoichet, Click chemistry functionalized polymeric nanoparticles target corneal epithelial cells through RGD-cell surface receptors, Bioconjugate Chem 20 (2009) 87-94.

[47] K. Temming, R.M. Schiffelers, G. Molema, R.J. Kok, RGD-based strategies for selective delivery of therapeutics and imaging agents to the tumour vasculature, Drug Resistance Updates 8 (2005) 381-402.

[48] A. Paillard, F. Hindré, C. Vignes-Colombeix, J.-P. Benoit, E. Garcion, The importance of endo-lysosomal escape with lipid nanocapsules for drug subcellular bioavailability, Biomaterials 31 (2010) 7542-7554.

[49] L. Grislain, P. Couvreur, V. Lenaerts, M. Roland, D. Deprez-Decampeneere, P. Speiser, Pharmacokinetics and distribution of a biodegradable drug-carrier, Int $\mathbf{J}$ Pharm 15 (1983) 335-345. 
[50] S.-D. Li, L. Huang, Stealth nanoparticles: high density but sheddable PEG is a key for tumor targeting, J Control Release 145 (2010) 178-181.

[51] C.H.J. Choi, J.E. Zuckerman, P. Webster, M.E. Davis, Targeting kidney mesangium by nanoparticles of defined size, PNAS 108 (2011) 6656-6661.

[52] S. Hirsjärvi, L. Sancey, S. Dufort, C. Belloche, C. Vanpouille-Box, E. Garcion, J.-L. Coll, F. Hindré, J.-P. Benoît, Effect of particle size on the biodistribution of lipid nanocapsules: Comparison between nuclear and fluorescence imaging and counting, Int J Pharm 453 (2013) 594-600.

[53] H. Maeda, T. Sawa, T. Konno, Mechanism of tumor-targeted delivery of macromolecular drugs, including the EPR effect in solid tumor and clinical overview of the prototype polymeric drug SMANCS, J Control Release 74 (2001) 47-61.

[54] Z. Hu, F. Luo, Y. Pan, C. Hou, L. Ren, J. Chen, J. Wang, Y. Zhang, Arg-Gly-Asp (RGD) peptide conjugated poly(lactic acid)-poly(ethylene oxide) micelle for targeted drug delivery, J Biomed Mater Res A 85A (2008) 797-807.

[55] M. Yoshimoto, K. Ogawa, K. Washiyama, N. Shikano, H. Mori, R. Amano, K. Kawai, $\alpha_{\mathrm{v}} \beta_{3}$ integrin-targeting radionuclide therapy and imaging with monomeric RGD peptide, Int J Cancer 123 (2008) 709-715.

[56] S. Monferran, N. Skuli, C. Delmas, G. Favre, J. Bonnet, E. Cohen-Jonathan-Moyal, C. Toulas, $\alpha_{v} \beta_{3}$ and $\alpha_{v} \beta_{5}$ integrins control glioma cell response to ionising radiation through ILK and RhoB, Int J Cancer 123 (2008) 357-364.

[57] A. Abdollahi, D.W. Griggs, H. Zieher, A. Roth, K.E. Lipson, R. Saffrich, H.-J. Gröne, D.E. Hallahan, R.A. Reisfeld, J. Debus, A.G. Niethammer, P.E. Huber, Inhibition of $\alpha_{\mathrm{v}} \beta_{3}$ integrin survival signaling enhances antiangiogenic and antitumor effects of radiotherapy, Clin Cancer Res 11 (2005) 6270-6279. 